\title{
Méthodologie d'étude des bovins trypanotolérants dans leur milieu d'élevage traditionnel du Nord de la Côte-d'lvoire
}

\author{
J.P. POIVEY and E. LANDAIS \\ Centre de Recherches Zootechniques \\ B.P. 673, Korhogo, Côte-d'Ivoire
}

Le Nord de la Côte-d'Ivoire, infesté de glossines, est peuplé de taurins indigènes trypanotolérants de petit format : la race $N^{\prime}$ Dama et la race Baoulé (West African Shorthorn). Sous l'effet d'un métissage croissant par les zébus sahéliens, qui répond aux besoins croissants en animaux de grande taille pour la culture attelée, les effectifs de la race Baoulé sont en constante régression. Le maintien de noyaux de races pures ne pourra être réalisé que si l'on met en place un contrôle massal de la population visant à la sélection des races taurines au sein même de leur milieu d'élevage.

Les auteurs décrivent un système de recueil d'information s'appuyant sur un suivi individuel des animaux et géré par des moyens informatiques. Ce système est adapté aux conditions particulières d'un élevage où les animaux, propriété d'agriculteurs, sont réunis dans des troupeaux communautaires gérés encore selon les coutumes traditionnelles. Actuellement 64 troupeaux de porcs villageois, regroupant 8000 têtes sont ainsi observés de façon continue.

A l'initiative des organismes chargés du développement, un important effort est consacré à la structuration de cet élevage villageois. Les premières réalisations concernent la séparation des jeunes taurillons du troupeau naisseur à l'âge d'un an et leur regroupement dans des lots à caractère coopératif où ils reçoivent un complément alimentaire à base de sous-produits agro-industriels. Ces actions visent à améliorer les conditions de la commercialisation des produits du troupeau. La recherche collabore étroitement avec le développement afin de fournir un outil de gestion technique de ces unités. L'enregistrement des performances pondérales des individus ainsi réunis en un milieu commun permet la comparaison des valeurs individuelles de la croissance et la mise en place d'une sélection sur ce caractère. Les performances d'un millier de taurillons sont annuellement enregistrées.

\section{Comparative study of the reproduction and the fattening performance of Creole and Large White pigs in Guadeloupe}

\author{
I. CANOPE and Y. RAYNAUD \\ Station de Recherches Zootechniques \\ I.N.R.A., Centre de Recherches Agronomiques Antille-Guyane, 97170 Petit-Bourg
}

Reproductive traits of Large White (LW) gilts were compared to Creole (Cr) gilts : age and weight at puberty are respectively $275.0 \pm 7.00$ days and $107.0 \pm 2.70 \mathrm{~kg}$ for the $L W$ and $171.4 \pm 3.54$ days and $52.3 \pm 2.00 \mathrm{~kg}$ for the local breed but no difference is observed between the intervals weaning-oestrus and weaning-successful mating. As for litter weight and litter size both at birth and at weaning these are significantly higher for the $L W$ sows.

Cr sow's maternal qualities must be emphasised $(8.5$ p. 100 mortality Vs 21.3 for the $L W$ ) and as a result sow productivity is almost the same for both the $L W$ and the $C r$ : 14.6 and 13.8 piglets per sow and per year respectively.

Growth rate and body composition are the following :

- the daily gain is significantly higher with the $L W$ breed $(514 \mathrm{Vs} 440$ for the local breed) and consequently the food conversion ratio is higher $(\mathrm{p}<0.01)$ with the $\mathrm{Cr}$ (4.0 Vs 3.30) than with the $L W$ pig;

- the percentage of muscle is significantly $(\mathrm{p}<0.01)$ greater with the $L W(47.0 \mathrm{p} .100$ Vs 39.0) than for the $\mathrm{Cr}$ by about 8 points. 